\title{
Constructively Managing Program-Related Conflict in Local Churches
}

Preprint from Christian Education Journal: Research on Educational Ministry

Vol. 16(2) pp. 259-274

\section{David R. Dunaetz}

Azusa Pacific University

\begin{abstract}
Interpersonal conflict surrounding church programs is a major source of distress for both pastoral staff and lay members of evangelical churches. Such conflict, when destructive, may severely hinder the achievement of program objectives. However, conflict when managed constructively may lead to a more effective program and strengthened relationships. This empirical study seeks to understand the conditions under which program-related conflict in evangelical churches leads to detrimental outcomes and those which lead to constructive outcomes. In a role-playing, surveybased experiment of American church attenders $(N=276)$, participants' satisfaction with conflict outcome was measured in a scenario with various outcomes concerning their program-related goal (maintaining the starting time of a mid-week children's program) and their social goals (e.g., having a better relationship with the director of the children's program, being affirmed in their Christian identity, and ensuring that decisions are made fairly). The study indicates that, in a conflict concerning a children's program, church attenders who have a salient social goal achieved, but not their program-related goal, will be more satisfied than church attenders who have their program-related goal achieved but not a salient social goal.
\end{abstract}

Keywords: Church, Christian Education, Conflict, Programs 


\section{Introduction}

As many pastors quickly discover after entering full-time ministry, new programs are often met with enthusiasm and rapid growth soon after they are initiated. However, once a major conflict develops, the momentum associated with the program stops and enthusiasm wains. The program's effectiveness may decrease and repercussions may be felt in other programs and among people not directly involved in the program where the conflict began. The consequences of such conflict can be devastating for the pastoral staff, individual members, and the church as a whole (Dunaetz, 2008; Gangel \& Canine, 1992; Susek, 1999; Tanner, Zvonkovic, \& Adams, 2012).

Yet sometimes what might be perceived as conflict leads to creative solutions of real problems, solutions that would not have been found unless the concerns of all the parties were understood and addressed (Dunaetz, 2016b; Tjosvold, 2008; Tjosvold, Wong, \& Feng Chen, 2014; Turner \& Pratkanis, 1997). This paper is an empirical study examining the conditions under which programrelated conflict in evangelical churches leads to detrimental outcomes and the conditions under which it leads to constructive outcomes. The focus is on understanding the variety of goals and desires that the individuals involved in the conflict have and the effect that achieving or not achieving these goals has on the individuals involved.

\section{Conceptual Overview}

\section{Organizational Programs}

Churches, like all organizations, exist for some purpose, either explicit or implicit. Some churches have well-articulated mission and vision statements; others have a general sense of why they exist, typically involving desires such as serving Christ, influencing others, or living out values within a community. In order to achieve these purposes, churches organize programs. A program can be defined as a "group of related activities that is intended to achieve one or several related objectives" (McDavid \& Hawthorn, 2006, p. 15). In the context of a local church, examples of programs include Sunday morning worship services (with objectives including worship, teaching, and perhaps evangelism), a food pantry (with an objective of ministering to the local poor), or a midweek children's program (perhaps with the objectives of teaching and evangelism).

Effective programs tend to have certain characteristics in common (Royse, Thyer, Padgett, \& Logan, 2006) such as sufficient resources, both material and staff. They fit into the organization's overall mission. They have a good reputation in the eyes of stakeholders, both those who provide the resources (e.g., staff and those who provide financial resources) and those who are beneficiaries of the program. They have policies and procedures that enable staff to carry out their responsibilities and to contribute to the organization's mission in an effective way. Yet, at the same time, these policies and procedures are viewed as benefitting the 
staff by responding to their own personal desires and objectives. Effective programs also tend to have a program theory which describes how staff actions are supposed to benefit the recipients of the program's services and thus achieve the program's objectives (Bickman, 1987; Funnell \& Rogers, 2011).

Effective programs also undergo evaluation. Because there is no definitive means by which a program's objectives are achieved, leaders of programs conduct program evaluation (McDavid \& Hawthorn, 2006; Royse, Thyer, Padgett, \& Logan, 2006) to some degree or another in order to answer such questions as "To what degree is this program achieving its objectives?", "How are the actual outcomes different from the intended outcomes?", and "To what degree is the program the cause of the observed outcomes?" (McDavid \& Hawthorn, 2006, pp. 15-17). Depending on the conclusions drawn by the program leaders, various aspects of the program may be changed to make the program more effective. However, a change in some aspect of a program, however valued it may be by the leader instigating the change, may not be appreciated by all who are affected by this change. If a person views the change as detrimental to achieving the objectives of the program, or if the change is personally costly, going against the person's own interests, conflict with the leader may arise.

\section{Children's Ministry}

As a context to study church-based conflict, this study focuses on a scenario involving a change in a midweek children's ministry. Children's ministries are among the most common programs within churches. The objectives of these programs typically include teaching children to pray, increasing bible literacy, providing elementary service opportunities, leading the children in worship, developing character, providing opportunities for personal reflection and meditation, increasing parental involvement in their children's spiritual development, and modeling Christian love in the teacher-child relationship (Beckwith, 2009; J. E. Myers, 2009). Many programs are effective in accomplishing at least some of these objectives (Firmin \& Clemans, 2010; Firmin \& Knight, 2007; Firmin, Kuhn, Michonski, \& Posten, 2005); other children's church-based programs have produced no detectable effect (Hartshorne \& May, 1928).

The effectiveness of children's programs may depend on the content of the program. Blanchette and Crosby (2016) found that children's programs which provided more reflection time had children more likely to be involved in service and to invite their friends to the program and that programs which emphasized more bible teaching saw more conversions, while programs which had fun interactive activities and media grew faster.

In addition to the goals and content of the program, the effectiveness of children's programs may also depend on their structure and their context. From the 1920 s to the 1950 s, many new and long-enduring children's programs were developed by parachurch organizations (e.g., AWANA and Pioneer Clubs; Lawson, 2003). These programs have often been adopted by local churches and 
incorporated into midweek activities which are a major part of the children's ministry in many churches (Csinos \& Beckwith, 2013; Houser, 2008). Firmin and colleagues have found that children who participated the most in an AWANA program grew in their beliefs that the Bible was important and considered the relationships that they developed with program leaders and the verses they memorized as contributing to their spiritual development (Firmin \& Clemans, 2010; Firmin \& Knight, 2007; Firmin, et al., 2005). In addition to benefiting children, these programs may contribute to the spiritual development of the volunteers who serve in the program (D. R. Myers, Wolfer, \& Garland, 2008) and may also provide the volunteers with psychosocial benefits (Omoto, Snyder, \& Martino, 2000). It is not clear how the programs affect the full time church staff members who are responsible for them. However, tenure before resignation from such positions tends to be only a few years, often occurring in a context of conflict (Lawson, 1994). Such resignations, when forced, can have severe negative consequences on the life of the church staff member (Tanner, Wherry, \& Zvonkovic, 2012; Tanner, Zvonkovic, et al., 2012).

\section{Conflict and Conflict-Related Goals}

Because programs are often adjusted or changed to potentially increase their effectiveness or to meet specific needs, interpersonal conflicts can arise between the various individuals involved. Interpersonal conflict can be defined as the "process that begins when an individual ... perceives differences and opposition between [himself or herself] and another individual . . . about interests and resources, beliefs, values, or practices that matter to them" (de Dreu \& Gelfand, 2008, p. 6). Just as programs have broad objectives to achieve, conflicts have less broad goals concerning the interests, resources, beliefs, values, or practices that fuel the conflict. These goals may be viewed as a person's "internal representations of desired states" (Austin \& Vancouver, 1996, p. 338). The desired states of each party involved in a conflict will depend on the individual, the context, and the interaction that the two parties have with each other. Each party may have multiple, concurrent goals in a given conflict (Ohbuchi \& Tedeschi, 1997). Understanding each other's conflict-related goals may enable each party to better manage the conflict.

Content Goals and Social Goals. Two broad categories used to understand interpersonal conflict-related goals are content goals and social goals. Content goals lie at the surface of conflicts and may involve resources, practices, policies, responsibilities or any other aspect of a conflict that is visible and relatively easy to discuss (such as the curriculum content, the time an activity is programmed to start, or the distribution of responsibilities). In contrast, social goals are far less visible and concern the social elements involving both parties and psychological processes that each party experiences (Jehn, 1997; Pruitt \& Kim, 2004). Since they are not as visible as content goals, social goals are difficult to identify and even more difficult to discuss because doing so reveals psychological 
and social vulnerabilities. Social goals may be classified as relationship goals, identity goals, and process goals (Dunaetz, 2014, 2016a; Wilmot \& Hocker, 2011).

Relationship Goals. Goals which concern how the disputants want to relate to and interact with one another may be classified as relationship goals. These goals focus on desired interpersonal processes and states involving the disputants (Curhan, Elfenbein, \& Xu, 2006; Jehn, 1997). These goals may include maintaining or increasing interdependence and having agreeable and mutually beneficial interactions. In Christian contexts, such goals are closely associated with Jesus' command to love one another (John 13:34, 15:12). Even in conflicts, people generally want to be trusted and believed, as well as to have supportive interactions with one another. These are examples of relationship goals.

Identity Goals. A second category of social goals in interpersonal conflicts concerns one's identity. These goals include how the people in conflict want to be perceived by themselves and others. They may include saving face or acting consistently with one's own values and behavior (Curhan et al., 2006; Wilmot \& Hocker, 2011). Behaving in a way consistent with one's values is an especially important identity goal in a Christian context because values are core elements of one's identity (Hitlin, 2003) and conscious inconsistency in one's values and behavior produces discomfort or distress (Festinger, 1957; cf. Peter in Matt. 26:75 and Judas in Acts 1:18). In addition, people typically want to be viewed as competent, morally and logically consistent, and worthy of respect, even in a conflict. These are typical identity goals. For evangelical Christians, identity goals are likely to include wanting to act in a Christ-like way or in accordance with the Bible. Helping people achieve their identity goals is especially important from a Christian education perspective: Development of one's identity as a Christian (and hence one's identity goals) may be viewed as the fundamental purpose of Christian education and spiritual formation (Beard, 2015, 2017).

Process Goals. A third category of conflict-related social goals concerns the process by which the conflict is managed and a solution is found. These goals concern the behavior of the two disputants during the conflict process. People tend to desire the conflict process to be just and fair (Curhan, et al., 2006; Ohbuchi \& Tedeschi, 1997). Thus these goals may include the desire to have a voice in the conflict or that an appropriate set of decision making rules (e.g., biblical norms of behavior) are used (Fisher, Ury, \& Patton, 1991; Wilmot \& Hocker, 2011). Process goals thus concern how the conflict will be managed and perhaps resolved. The desire to provide input into the situation, the desire to understand how a decision is made, and the desire for fairness are all process goals that are likely to be present in program-related conflict.

In Christian ministry contexts, all of these goals will be present whenever interpersonal conflicts arise, including program-related conflicts. Church staff, program leaders, parents, other church members, and those on the periphery of the church will all have a variety of content and social goals depending on the conflict. The degree to which their goals are achieved in a conflict will influence the 
likelihood that that they will remain involved with and be committed to the program, and even the church (Dunaetz, 2011; Harman, Lee, Mitchell, Felps, \& Owens, 2007; Leiter \& Maslach, 1988). However, the relative importance of each of these types of goals in program-related conflict in evangelical churches has not previously been examined. This study examines the relationship of content goal and social goal achievement (or non-achievement) to satisfaction with the outcome of program-related conflict such as pastoral staff and program leaders may encounter. Understanding this relationship should help church leadership to better manage the conflict and to minimize the damage that could occur to both the program in question and, even more importantly, to the people who are supposed to benefit from the program.

\section{Hypotheses Predicting What Satisfies Christians in Program-Related Conflicts}

Because multiple goals are present in program-related conflict, it is important that the church leader understand the importance of these goals in order to manage the conflict so as to find the best possible outcomes for all parties involved. Since both content and social goals are present in program-related conflict, it is likely that the achievement or non-achievement of each type of goal will contribute to the disputants' level of satisfaction with the outcome. This first hypothesis can be stated as:

$\mathrm{H}_{1}$ : In a conflict concerning some elements of a church program, the achievement of content goals and social goals (including relationship goals, identity goals, and process goals) increases satisfaction with the conflict outcome.

If this is indeed the case, church leaders, when faced with program-related conflict, need to take into consideration all types of conflict-related goals when attempting to manage the conflict.

Furthermore, because the social aspect of the Christian life is so important, it is possible that conflict-related social goals (e.g., goals concerning relationships, values, or fairness) will be more important to church attenders than the conflict-related content goals (e.g., goals concerning the starting time of a program). Thus, when both a program-related content goal and a social goal are salient in a conflict, we can hypothesize the following:

$\mathrm{H}_{2}$ : In a conflict concerning an element of a church program, church attenders who have a salient social goal achieved, but not their content (program-related) goal, will be more satisfied than church attenders who have their content (program-related) goal achieved but not a salient social goal. 
If this second hypothesis is true, it indicates that church leaders need to work on finding solutions which prioritize making sure the disputants achieve their social goals, specifically their social goals which are congruent with the values of the gospel and which do not require resources that the leader may not be able to provide (as may be the case with a content goal).

\section{Method}

In the context of a broader study using prospect theory (Kahneman, 2011; Kahneman \& Tversky, 1979) to understand conflict and conflict goals in evangelical churches (Dunaetz, 2014), 276 church attenders participated in an online role-playing experiment in which they imagined themselves in a programrelated conflict. When presented with various outcomes to this conflict, they indicated how satisfied they would be with each of the outcomes.

\section{Participants}

Starting with electronic distribution lists available to the author, people identified as evangelicals received a message inviting them to participate in a survey about their church experiences. Using a snowball sampling technique (Goodman, 1961) known as respondent-driven sampling (Heckathorn, 1997), 276 active attenders of evangelical churches were recruited and completed an online survey used to present the experiment to them. Participants were asked to name a non-profit organization of their choice which would receive a $\$ 5.00$ gift in order to thank the participants for their time. The participants were also encouraged to send the link to the survey to their friends who could also choose an organization that would receive the gift. Wycliffe Bible Translators was the most commonly chosen organization.

The average age of the participants was 50.1 years. The majority were female (64\%), had college degrees or above (74\%), lived in North America (94\%), and identified themselves as White $(86 \%)$.

\section{Procedure}

After giving their consent to participate in this study, participants were asked to imagine themselves experiencing various conflicts in a church. The program-related conflict was:

Imagine you are a parent of a 5 year old and a 7 year old who are involved in a Wednesday night children's program at church. The director of the program has recently announced that he is going to change the starting time of the program from $7 \mathrm{pm}$ to $8 \mathrm{pm}$ so that parents aren't so rushed after work to bring their children to the program. You believe that this is too late for your children and that it will not be good for any of the 
children to have a program that runs so late into the evening. Your goals are to get the beginning time changed back to $7 \mathrm{pm}$, to maintain and even strengthen your relationship with the director, to act in a loving, Christlike way, and to make sure that decisions are made fairly.

Participants were then randomly assigned to two groups. In one group their content (program-related) goal was achieved, "The program director decided to move the starting time back to $7 \mathrm{pm}$...." In the other group, their content goal was not achieved, "The program director decided to keep the starting time at $8 \mathrm{pm}$...."

Each participant was asked to indicate how satisfied they would be for two possible conflict outcomes. In addition to being assigned to groups where their content goal was achieved or not achieved, participants were also assigned to one of three groups where one of their three social (i.e., relationship, identity, or process) goals were achieved or not achieved. They indicated how satisfied they would be with the conflict outcome when the social goal was achieved and when it was not achieved. For example, those assigned to the relationship goal group indicated first how satisfied they would be if the conflict outcome included the achievement of their relationship goal "... he [the program director] spoke to you in a way that built up the relationship and made you trust him more." Then they indicated how satisfied they would be if the conflict outcome included the nonachievement of their relationship goal "... he [the program director] spoke to you in a way that hurt your relationship and made you trust him less."

The outcomes for those in the identity goal group were "... you acted in a loving, Christ-like way when you discussed it with [the program director]" and ". . you did not act in a loving, Christ-like way when you discussed it with [the program director]." In these outcomes, the participants either acted congruently or incongruently with their identity as Christians. Acting congruently about one's beliefs about self is a typical identity goal.

The outcomes for those in the process goal group were "... he [The program director] explained to you how the decision was made in a fair and just way" and ". . . he [The program director] refused to discuss with you how and why this decision was made." In these outcomes, the participant's process goal of having the decision being made in a fair and just way was either achieved or not achieved.

Thus each participant indicated their satisfaction with two conflict outcomes. Some were in groups where the content (program-related) goal was achieved and indicated how satisfied they would be if one of their social (relationship, identity, or process) goals was achieved and how satisfied they would be if it was not achieved. Others were in groups where the content (program-related) goal was not achieved and likewise indicated how satisfied they would be if one of their social (relationship, identity, or process) goals was achieved and how satisfied they would be if it was not achieved.

\section{Measure of Conflict Outcome Satisfaction}


To measure a participant's conflict outcome satisfaction, each participant responded to three questions. First, they responded to the question "What is your global evaluation of this outcome?" on a scale going from 1 (= Terrible) to 6 (= Excellent). Second, they responded to the question "How satisfied would you be with this outcome?" on a scale from 1 (= Extremely Dissatisfied) to 10 (= Extremely Satisfied). Finally they were presented a series of six cartoon faces which varied from very sad to very happy (Kunin, 1955); they were asked to choose the face that best represented their global satisfaction with the conflict outcome. Scores for these three scales were added, yielding a composite score with a potential range of 3 to 23 with a neutral point of 13 (scores above 13 indicated a trend toward satisfaction; scores below 13, dissatisfaction). For all six conditions ( 2 content goal conditions $\times 3$ social goal conditions), the coefficient of reliability (Cronbach, 1951) for the conflict satisfaction outcome was very good $(\alpha>.75$; for details, see Dunaetz, 2014).

As a reminder, the content goal was to have the program starting time changed back to $7 \mathrm{pm}$. The three social goals were to have a better relationship with the program director (a relationship goal), act in a loving, Christ-like way (an identity goal), and to make sure that the decision was made fairly (a process goal).

\section{Results}

\section{Analysis Strategy}

Means and standard deviations of satisfaction with conflict outcome were computed using SPSS (IBM, 2016) for all combinations of conflict outcomes. Significant differences between conditions for the mean conflict outcomes were tested with $t$-tests, as were differences between changes of conditions.

\section{Do Both Program-Related Goals and Social Goals Matter?}

The first hypothesis predicted that the achievement of both the content and the social goals contribute to satisfaction with the conflict outcome. When the content goal (program starting time) was not achieved, the mean satisfaction with the conflict outcome (across all social goal outcomes) was only $10.27(S D=3.70$, $N=276$ ) while the mean satisfaction when the content goal was achieved was $15.96(S D=3.87, N=276)$. Recall that scores less than 13 indicate dissatisfaction and scores higher than 13 indicate satisfaction. The difference between these scores, unsurprisingly, was significant $(t=47.17, d f=274, p<.001,1$-tailed). However, more importantly, the achievement of the social goal contributed to satisfaction with the outcome, regardless of whether the program's starting time was changed or not. When the social goal was not achieved, the mean satisfaction with the conflict outcome was only $8.58(S D=3.73, N=276)$ but when the social goal was achieved, the mean satisfaction increased to $17.39(S D=5.21, N=276)$. This difference was once again significant $(t=35.03, d f=274, p<.001,1$-tailed). Whereas achieving the content goal (obtaining the desired starting time) resulted in 
a 5.68 point gain in satisfaction, achieving a social goal resulted in an average gain of 8.81 points across all social goals. Further analyses indicated more specifically that the change in satisfaction gained by achieving the relationship goal (building up the relationship and increasing trust between the parties) was 10.00 points, the change gained by achieving the identity goal (acting in a loving, Christ-like way) was 8.56 , and the change gained by achieving the process goal (making sure that the decision was made in a fair and just way) was 7.63 points. All of these differences were significant ( $t \mathrm{~s} \geq 14.48, d f \mathrm{~s}$ ranging from 81 to $100, p \mathrm{~s}<.001,1$ tailed). Thus the first hypothesis was fully supported: Achieving either content (the starting time) goals or social (relationship, identity, or process) goals increases satisfaction.

\section{Are Social Goals More Important than Program-Related Goals?}

The second hypothesis predicted that church attenders who achieved a salient social goal (but not their content goal concerning the starting time of the program) would be more satisfied with the conflict outcome than people who achieved their content goal concerning the starting time but did not achieve a salient social goal. In general, this hypothesis was supported. It was fully supported when combining all social goals and when two of the specific social goals were examined individually; it was partially supported when the third social goal was examined apart from the others.

The mean satisfaction when only the participant's content (programrelated) goal was achieved was only $10.52(S D=3.91, N=132)$, but the mean satisfaction when only the social goal was achieved was $13.74(S D=4.37, N=$ 144). Recall that 13.00 was the neutral point. Satisfaction scores above 13 (as was the case when only the social goal was achieved) indicate a tendency towards overall satisfaction with the conflict outcome, while scores below 13 (as is the case when only the content goal was achieved) indicate dissatisfaction. The difference between these two satisfaction scores was significant $(t=6.42, d f=274, p<.001$, 1-tailed). People who obtained the starting time they desired but did not achieve their social goal were dissatisfied with the outcome. People who obtained their social goal, but who were not able to obtain the starting time they desired were generally satisfied with the outcome.

Further analyses tested the second hypothesis by examining the outcomes for each of the social goal conditions separately. When participants achieved their content (program-related) goal but not their relationship goal (the program director spoke in a way that hurt the relationship and made the participant trust him less), the mean satisfaction with the conflict outcome was $10.02(S D=3.52, N=58)$. However when they achieved only their relationship goal (the program director spoke in such a way as to build up the relationship and make the participant trust him more), but not the content (program-related) goal, their satisfaction with the outcome was $15.20(S D=4.19, N=44)$. The difference between these two satisfaction scores was significant $(t=6.79, d f=100, p<.001,1$-tailed $)$. This 
means that the relationship with the program director was far more important to most Christians than the starting time.

Similar results were obtained when testing the second hypothesis with the identity goal. When participants achieved their content (program-related) goal but not their identity goal (they did not act in a loving, Christ-like way when discussing the topic with the program director), their satisfaction with the outcome was $9.49(S D=2.83, N=39)$. However, when they achieved their identity goal (they acted in a loving, Christ-like way) but not their content (program-related) goal (the starting time which they believed to be inappropriate was maintained), their satisfaction with the outcome was $12.44(S D=4.19, N=52)$. The difference between these two satisfaction scores was significant $(t=3.80, d f=89, p<.001$, 1 -tailed). This means that acting in accordance with their values was more important for most Christians than the starting time of the program.

Results were less conclusive for the process goal. When participants achieved their content (program-related) goal but not their process goal (the program director refused to discuss how and why this decision was made), their satisfaction with the conflict outcome was $12.51(S D=4.83, N=35)$. However, when they achieved their process goal (the program director explained to them how the decision was made in a fair and just way) but not their content (programrelated) goal, satisfaction was $13.79(S D=4.37, N=48)$. Thus the satisfaction when only the process goal was achieved was higher than when only the content (program-related) goal was achieved, as hypothesized, but this difference was not significant $(t=1.26, d f=81, p=.11,1$-tailed). This means that a difference in satisfaction scores this large would have an $11 \%$ chance of occurring randomly in a sample of this size if, in fact, there was no difference in satisfaction between the two conflict outcomes in the general population.

\section{Discussion and Implications}

Using a role-playing, online experiment involving evangelical Christians, this study has demonstrated the importance of relationship, identity, and process goals in program-related conflicts in local churches. Specifically, Christians were more satisfied when their social goals (i.e., their relationship, identity, and process goals), but not their content goal, were satisfied than when their content goal (the goal of changing the starting time of the program), but not their social goals, was achieved. This leads to several important implications.

First, the types of conflict goals described in the literature (Curhan, et al., 2006; Jehn, 1997; Ohbuchi \& Tedeschi, 1997; Wilmot \& Hocker, 2011) are confirmed to be present in ministry contexts. Christians have both content and social goals (including relationship goals, identity goals, and process goals) in conflicts which they desire to achieve. Whether they achieve them or not influences their satisfaction with the conflict outcomes.

Second, church staff and lay leaders need to be aware of the importance of social goals. Whether a fellow Christian's social goals are achieved or not is likely to have a greater impact on the conflict outcome than whether or not the 
other party obtains what he or she desires concerning the program. The importance of relationship, identity, and process goals is completely congruent with a biblical emphasis on love, Christ-centered values, and justice. Even when a program leader cannot respond to a person's desires concerning the content (program-related) goal, he or she can respond with love, affirmation of the other party's Christian values, respect, and fairness. Such responses are never impossible due to limited resources or undesirable consequences.

Third, church staff, lay leaders, and all church members can benefit from training in conflict dynamics and resolution. Such training needs to focus on both conflict management theory and realistic scenarios that might occur in the church's programs. This study has demonstrated the importance of conflict goals in ministry settings. The more church members are aware of them, the better equipped they are to deal constructively with conflict. Other topics to include in such a training might include conflict styles, power dynamics, emotions, and negotiation (Wilmot $\&$ Hocker, 2011). Additional topics, depending on the needs of the church or the specific program, could include organizational justice (Dunaetz, 2010) and program evaluation (McDavid \& Hawthorn, 2006; Royse, et al., 2006). Such training could occur in the context of in-service training for members involved in the educational ministry of the church, in the context of marriage strengthening ministries, in the youth program, or even through a series of Sunday messages with discussions and application occurring in small groups throughout the week. A conflict resolution seminar could also be held as a stand-alone activity, perhaps as a community outreach project.

Fourth, churches need to have a mediation system in place to help members constructively resolve conflict when it arises. A system for resolving disputes is a fundamental biblical requirement for church structure (I Cor. 6:1-11), but it is often sorely missing from contemporary North American churches. A board of elders or deacons can serve this purpose, but these boards are often preoccupied with other matters. Another structure which can serve this purpose is the wisdom council (Hellerman, 2017), an ad hoc group that can be convoked for situations requiring wisdom, such as when a church member is facing difficult life decisions or is in a conflict with another Christian. When church members are facing such a situation, they can contact the person who coordinates this ministry who, in turn, will gather together a group of wise people (such as one staff member and several lay members) who are trusted by the parties involved and who have relevant life experience.

\section{Limitations}

Although this study was a true experiment and not subject to the limitations of correlational studies, several limitations should be noted. First, as a role-playing experiment, participants were asked to imagine how they would have responded to emotional issues. Although humans are very good at forecasting the valance and strength of their emotional reaction to an event (Wilson \& Gilbert, 2003), they are not very good at estimating how these emotions will evolve over 
time (Wilson, Wheatley, Meyers, Gilbert, \& Axsom, 2000). How emotions evolve have strong social implications that were not considered in this present study. Second, the situations in this study only presented the outcome of one social goal in each situation. Actual conflicts are much more complicated, with multiple social goals achieved or not achieved to various degrees. Future studies should examine actual conflicts that participants have experienced in ministry settings. Such studies can examine Christians' responses to complex situations, how they have evolved over time, and how they impacted the ministries.

\section{Conclusion}

This study has demonstrated the importance of content goals (e.g., the starting time of a children's program) and social goals in ministry-related conflict. These social goals may include relationship goals (e.g., having a better relationship with the program director), identity goals (e.g., acting in a loving, Christ-like way) and process goals (e.g., making sure decisions are made fairly). In this experiment, achieving or not achieving one's social goals had a greater impact on one's satisfaction with the conflict outcome than did the achievement or nonachievement of content goals. This demonstrates the importance of focusing on social goals to resolve interpersonal, program-related conflict in constructive ways in churches. Resolving conflict more constructively will enable leaders of church programs to better accomplish the purposes of these programs.

\section{References}

Austin, J. T., \& Vancouver, J. B. (1996). Goal constructs in psychology: Structure, process, and content. Psychological Bulletin, 120,338-375.

Beard, C. B. (2015). Missional discipleship: Discerning spiritual-formation practices and goals within the missional movement. Missiology, 43, 175-194.

Beard, C. B. (2017). Connecting spiritual formation and adult learning theory: An examination of common principles. Christian Education Journal, 14, 247-269.

Beckwith, I. (2009). Postmodern children's ministry: Ministry to children in the 21st century church. Grand Rapids, MI: Zondervan.

Bickman, L. (1987). The functions of program theory. New Directions for Evaluation, 33, 5-18.

Blanchette, L., \& Crosby, R. G. (2016). The measurement and evaluation of children's ministry praxis. Christian Education Journal, 13, 247-265.

Cronbach, L. J. (1951). Coefficient alpha and the internal structure of tests. Psychometrika, $16,297-334$.

Csinos, D. M., \& Beckwith, I. (2013). Children's ministry in the way of Jesus. Downers Grove, IL: InterVarsity Press.

Curhan, J. R., Elfenbein, H. A., \& Xu, H. (2006). What do people value when they negotiate? Mapping the domain of subjective value in negotiation. Journal of Personality and Social Psychology, 91, 493-512.

de Dreu, C. K. W., \& Gelfand, M. J. (Eds.). (2008). The psychology of conflict management in organizations (pp Pages). New York, NY: Lawerence Erlbaum Associates. 
Dunaetz, D. R. (2008). Transforming chaos into beauty: Intentionally developing unity in church plants. Evangelical Missions Quarterly, 44, 358-365.

Dunaetz, D. R. (2010). Organizational justice: Perceptions of being fairly treated. In D. Baker \& D. Hayward (Eds.), Serving Jesus with integrity: Ethics and accountability in mission (pp. 197-221). Pasadena, CA: William Carey Library.

Dunaetz, D. R. (2011). Personality and conflict style: Effects on membership duration in voluntary associations. Saarbrücken, Germany: Lambert Academic Press.

Dunaetz, D. R. (2014). The achievement of conflict-related goals leads to satisfaction with conflict outcomes. CGU Theses \& Dissertations. Paper 89. http://scholarship.claremont.edu/cgu etd/89.

Dunaetz, D. R. (2016a). Mission in evolving cultures: Constructively managing musicrelated conflict in cross-cultural church planting contexts. Missiology: An International Review, 44, 296-310.

Dunaetz, D. R. (2016b). Submission or cooperation? Two competing approaches to conflict management in mission organizations. In R. Cathcart Scheuermann \& E. L. Smither (Eds.), Controversies in mission: Theology, people, and practice in the 21st century (pp. 121-142). Pasadena, CA: William Carey Library.

Festinger, L. (1957). A theory of cognitive dissonance. Evanston, IL: Row, Peterson and Co.

Firmin, M. W., \& Clemans, A. (2010). Six-year outcome effects of former Timothy-Award recipients. Christian Education Journal, 7, 52-69.

Firmin, M. W., \& Knight, G. E. (2007). Three-year outcome effects of former AWANA Timothy-Award recipients. Christian Education Journal, 4, 100-116.

Firmin, M. W., Kuhn, P. C., Michonski, J. D., \& Posten, T. N. (2005). From outside-in to inside-out: A qualitative analysis of childhood motivation by achievers in AWANA programs. Christian Education Journal, 2, 77-96.

Fisher, R., Ury, W., \& Patton, B. (1991). Getting to yes: Negotiating agreement without giving in. New York, NY: Penguin Books.

Funnell, S. C., \& Rogers, P. J. (2011). Purposeful program theory: Effective use of theories of change and logic models. San Francisco, CA: John Wiley \& Sons.

Gangel, K. O., \& Canine, S. L. (1992). Communication and conflict management in churches and Christian organizations. Nashville, TN: Broadman \& Holman.

Goodman, L. A. (1961). Snowball sampling. The Annals of Mathematical Statistics, 32, 148-170.

Harman, W. S., Lee, T. W., Mitchell, T. R., Felps, W., \& Owens, B. P. (2007). The psychology of voluntary employee turnover. Current Directions in Psychological Science, 16, 51-54.

Hartshorne, H., \& May, M. A. (1928). Studies in the nature of character: Studies in deceit. New York, NY: Macmillan.

Heckathorn, D. D. (1997). Respondent-driven sampling: A new approach to the study of hidden populations. Social Problems, 174-199.

Hellerman, J. H. (2017). Why we need the church to become more like Jesus: Reflections about community, spiritual formation, and the story of scripture. Eugene, OR: Wipf and Stock Publishers.

Hitlin, S. (2003). Values as the core of personal identity: Drawing links between two theories of self. Social Psychology Quarterly, 66, 118-137.

Houser, T. (2008). Building children's ministry: A practical guide. Nashville, TN: Thomas Nelson.

IBM. (2016). Ibm spss statistics for windows, version 24.0. Armonk, NY: IBM Corp.

Jehn, K. A. (1997). A quantitative analysis of conflict types and dimensions in organizational groups. Administrative Science Quarterly, 42, 530-557. 
Kahneman, D. (2011). Thinking, fast and slow. New York, NY: Farrar, Straus and Giroux.

Kahneman, D., \& Tversky, A. (1979). Prospect theory: An analysis of decision under risk. Econometrica: Journal of the Econometric Society, 263-291.

Kunin, T. (1955). The construction of a new type of attitude measure. Personnel Psychology, 8, 65-77.

Lawson, K. E. (1994). Former directors of Christian education — why they left: Implications for the profession. Christian Education Journal, 14, 46-63.

Lawson, K. E. (2003). Marginalization and renewal: Evangelical Christian education in the twentieth century. Religious Education, 98, 437-453.

Leiter, M. P., \& Maslach, C. (1988). The impact of interpersonal environment on burnout and organizational commitment. Journal of Organizational Behavior, 9, 297-308.

McDavid, J. C., \& Hawthorn, L. R. L. (2006). Program evaluation \& performance measurement: An introduction to practice. Thousand Oaks, CA: Sage Publications.

Myers, D. R., Wolfer, T. A., \& Garland, D. R. (2008). Congregational service-learning characteristics and volunteer faith development. Religious Education, 103, 369386.

Myers, J. E. (2009). Children's spiritual development: Analysis of program practices and recommendations for early childhood professionals. Doctor of Education Dissertation, University of North Texas.

Ohbuchi, K. I., \& Tedeschi, J. T. (1997). Multiple goals and tactical behaviors in social conflicts. Journal of Applied Social Psychology, 27, 2177-2199.

Omoto, A. M., Snyder, M., \& Martino, S. C. (2000). Volunteerism and the life course: Investigating age-related agendas for action. Basic and applied social psychology, 22, 181-197.

Pruitt, D. G., \& Kim, S. H. (2004). Social conflict: Escalation, stalemate, and settlement (3rd ed.). Boston, MA: McGraw Hill.

Royse, D., Thyer, B. A., Padgett, D. K., \& Logan, T. K. (2006). Program evaluation: An introduction. Belmont, CA: Brooks Cole.

Susek, R. (1999). Firestorm: Preventing and overcoming church conflicts. Grand Rapids, MI: Baker Books.

Tanner, M. N., Wherry, J. N., \& Zvonkovic, A. M. (2012). Clergy who experience trauma as a result of forced termination. Journal of Religion and Health, 1-15. doi: doi:10.1007/s10943-012-9571-3.

Tanner, M. N., Zvonkovic, A. M., \& Adams, C. (2012). Forced termination of American clergy: Its effects and connection to negative well-being. Review of Religious Research, 54, 1-17.

Tjosvold, D. (2008). The conflict-positive organization: It depends upon us. Journal of Organizational Behavior, 29, 19-28.

Tjosvold, D., Wong, A. S. H., \& Feng Chen, N. Y. (2014). Constructively managing conflicts in organizations. Annual Review of Organizational Psychology and Organizational Behavior, 1, 545-568.

Turner, M. E., \& Pratkanis, A. R. (1997). Mitigating groupthink by stimulating constructive conflict. In C. K. W. de Dreu \& E. van de Vliert (Eds.), Using conflict in organizations (pp. 53-71). Thousand Oaks, CA: Sage Publications.

Wilmot, W. W., \& Hocker, J. L. (2011). Interpersonal conflict (8th ed.). New York, NY: McGraw Hill.

Wilson, T. D., \& Gilbert, D. T. (2003). Affective forecasting. Advances in Experimental Social Psychology, 35, 345-411. 
Program-Related Conflict in Churches

Wilson, T. D., Wheatley, T., Meyers, J. M., Gilbert, D. T., \& Axsom, D. (2000). Focalism: A source of durability bias in affective forecasting. Journal of Personality and Social Psychology, 78, 821-836. 